\title{
ENCAPSULATION OF RESVERATROL IN SPHERICAL PARTICLES OF FOOD GRADE HYDROGELS
}

\author{
Bojana D. Balanč ${ }^{* 1}$, Kata T. Trifković ${ }^{1}$, Radoslava N. Pravilović ${ }^{1}$, Verica B. Đorđević ${ }^{1}$, Smilja \\ B. Marković ${ }^{2}, V^{2}$ iktor A. Nedović ${ }^{3}$, Branko M. Bugarski $^{1}$ \\ ${ }^{1}$ University of Belgrade, Faculty of Technology and Metallurgy, Department of Chemical Engineering \\ ${ }^{2}$ Institute of Technical Sciences of the Serbian Academy of Sciences and Arts \\ ${ }^{3}$ University of Belgrade, Faculty of Agriculture, Department of Food Technology and Biochemistry
}

${ }^{*}$ Corresponding author

Tel.: +381113370471

Fax: +381113370387

email: bisailovic@tmf.bg.ac.rs

\begin{abstract}
The paper reports about the preparation and characterization of hydrogel particles containing liposomes loaded with resveratrol as an active compound. The materials used for preparation of the particles were chosen to be suitable for food industry. Different polymer concentrations affect particles shape, size, size distribution, as well as the release kinetics of resveratrol. The diameter of particles varied from 360 to $754 \mu \mathrm{m}$, while the narrow size distribution was observed for all types of particles. Release studies were performed in Franz diffusion cell and the results showed the prolonged release of resveratrol from all samples, but the sample with the highest content of polymer $(2.5 \% \mathrm{w} / \mathrm{w})$ in particular stood out. The research provides useful information about liposomes containing active compound encapsulated in hydrogel matrices and offers the basis for its application in the food industry.
\end{abstract}

Key words: resveratrol, sodium alginate, release, sphericity, particles

\section{INTRODUCTION}

Resveratrol is a natural antioxidant with remarkable antioxidant activity, found in grapes and red wines (Stojanović et al., 2001, Lim et al., 2014). It is also highly sensitive compound and poorly soluble in water surrounding (Lopez-Nicolas et al., 2006; Pineiro et al., 2006). Therefore, its application is uncommon although resveratrol possesses strong antioxidant properties. Nowadays, functional food with addition of highly valuable antioxidants attracts attention of both, consumers and producers, as well as researchers (Đorđevic et al., 2015). In order to use sensitive antioxidants in functional food products it is necessary to protect them in a certain way. For that purpose, encapsulation techniques are found to be convenient (Belščak-Cvitanović et al., 2011; Stojanović et al.,2012; Đorđevic et al., 2015; Istenič et al., 2015) and among them electrostatic extrusion stands out as non-invasive one. In addition, it has been demonstrated that particles obtained via electrostatic extrusion technique have very narrow size distribution (Bugarski et al., 2004), which is important from the application aspect. Unfortunately, due to poor solubility of resveratrol in water, its direct encapsulation in hydrogel particles is not possible. As it was described by Isailović et al. (2013) resveratrol can be 
encapsulated in liposomes with high encapsulation efficiency, using simple and easy-scalable cost effective proliposome technique. However, the stability of liposome formulations is often under suspicion so that it constrains their application, especially in food industry. In order to overcome this problem, liposomal emulsion with encapsulated resveratrol can be further incorporated in hydrogel particles. In this work, liposomal suspension with encapsulated resveratrol was mixed with different concentrations of food grade polymer - sodium-alginate (two types of sodium-alginate with different molecular weight) and the mixture was subjected to electrostatic extrusion to obtain micronized particles. The particles were further characterized in terms of size and shape. The release profile of resveratrol from the particles was also determined and discussed. Thus, this study provides useful information for potential application of the multipart system liposome-activehydrogel into functional food products.

\section{MATERIALS AND METHODS}

\section{Materials}

Phospholipon 90 NG (more than 90\% phosphatidilcholine (PC) was supplied by Natterman Phospholipids (Germany). Trans-resveratrol standard (>99\% pure) was obtained from ChromaDex (Irvine, CA, USA). Low viscosity sodium-alginate (LV, molecular weight: 12000-80000), and medium viscosity sodium-alginate (MV, molecular weight: 80000-120000) ware purchased from Sigma-Aldrich (Germany). Calcium-chloride dehydrate, $99 \%$ was obtained from Acros organics, USA. All other chemical used were of analytical grade.

\section{Liposome preparation}

Liposomes were prepared using simple proliposome method. Commercial lipid mixture Phospolipon 90NG (P90NG) was used in this step according to Isailović et al. (2013). Briefly, P90NG was mixed with ethanol, resveratrol and small quantity of water and stirred with magnetic stirrer at $60{ }^{\circ} \mathrm{C}$. When the mixture was homogenized, it was further cooled to room temperature and then $50 \mathrm{ml}$ of distilled water was added in small portions. The obtained suspension was stirred for one more hour at $800 \mathrm{rpm}$. The final concentration of the lipids was $20 \mathrm{mg} / \mathrm{ml}$. The ratio between resveratrol and lipids was $1: 20 \mathrm{w} / \mathrm{w}$.

\section{Preparation of calcium alginate particles}

Alginate particles containing liposomes were prepared as described by Balanč et al. (2016) with slight modifications. In brief, the solutions were prepared by dissolving sodium-alginate in distilled water and then mixed with previously prepared liposome suspension in volume ratio $2: 3$ to obtain final concentration of sodium alginate 1.0, 1.5 and $2.5 \% \mathrm{w} / \mathrm{v}$. The same procedure was done for both LV and MV alginate. These solutions were then extruded through a blunt stainless steel needle (23 G) using a syringe pump (Razel Scientific Instruments, Stamford, CT, USA) into $2 \%$ $\mathrm{w} / \mathrm{v}$ calcium-chloride under an applied electric field of $6.3 \mathrm{kV}$. The microbeads were formed in contact with calciumchloride solution and then left in the solution for 15 min (Bugarski et al., 1994).

\section{Optical microscopy}

Optical microscope was employed for observation of the particles (Olympus CX41RF, Tokyo, Japan). Using ImageJ software the images were analyzed and the sphericity factor (SF) of the particles was calculated according to Chan et al. (2011b):

$$
S F=\frac{\left(l_{\text {max }}-l_{\text {min }}\right)}{\left(l_{\text {max }}+l_{\text {min }}\right)}
$$

where $I_{\max }(\mu \mathrm{m})$ is the largest diameter and $I_{\min }(\mu \mathrm{m})$ is the smallest diameter perpendicular to $I_{\max }$. $(\mu \mathrm{m})$. SF was calculated from the 50 beads sample. SF varies from zero for a perfect sphere, to approaching unity as the particle becomes more elongated.

\section{Particles size and size distribution}

The size of particles (surface mean diameter) and size distribution were measured by a laser light scattering particle size analyser (PSA) (Mastersizer 2000; Malvern Instruments Ltd., Malvern, Wor- 
cestershire, U.K.). The particle size distribution was characterized through the values of SPAN, which was calculated as follows:

$S P A N=\frac{\left(d_{90}-d_{10}\right)}{d_{50}}$

where $d_{10}, d_{50}$ and $d_{90}$ are the intercepts for $10 \%, 50 \%$ and $90 \%$ of the cumulative particles number.

\section{Release behaviour}

The release studies were performed in Franz diffusion cell (donation of PermeGear, Inc., USA). Two cell compartments were separated with acetatecellulose membrane (pore size of $0.2 \mu \mathrm{m}$ ). Around $2 \mathrm{~g}$ of the microbeads was placed in the donor compartment while the receptor compartment was filled with ethanol $50 \%(20 \mathrm{ml})$ and constantly mixed at 400 rpm (Klimundova et al., 2006).

The aliquots of $0.5 \mathrm{ml}$ were taken in time intervals during 6 hours and replaced with the same amount of fresh medium. Resveratrol concentration was determined by spectrophotometry at $306 \mathrm{~nm}$ as described by Neves et al. 2016 .

\section{RESULTS AND DISCUSSION}

\section{Particle shape and size}

Preparation of particles using electrostatic extrusion depends on several operating parameters which impact its size and shape (Kostić et al., 2012). Hence, viscosity of the starting polymer solution which correlates to its concentration had influence on sphericity and diameter of the droplets generated in the electric field, as described by Prüsse et al. (2008). Concerning, our study showed that polymer solution consisted of $2.5 \%$ medium viscosity alginate (MV 2.5\%) was not appropriate for particles preparation since it was impossible to process it.

Therefore, this sample was not used in further investigations. On the other hand, the utilization of other MV polymer solutions provided spherical particles with sphericity factor lower than 0.04 (Table 1).

Namely, Chan et al. (2011a) reported that values of SF smaller than 0.05 should be considered as spherical. The results also imply on slight decrement of the SF value with increasing alginate concentration.

This effect could be explained by better molecular packing in samples with higher alginate concentration (Trifković et al., 2014). In addition to particles shape, optical microscopy (Figure 1) also gave visualisation of the particles.

PSA showed that surface mean diameter (D [3,2]) varied from $368 \mu \mathrm{m}$ to $755 \mu \mathrm{m}$ (Table 1) and it was also correlated with the concentration of the starting solution. More concentrated solutions provided particles with larger diameter which was expected (Prüsse et al., 2008; Kostić et al., 2012).

The particles size distribution is also important data for their potential application (Prüsse et al., 2008). Therefore, the samples were analyzed by a laser light scattering and the results showed narrow size distribution in all samples as shown in Figure $2($ SPAN $<1)$. The values of SPAN were smaller $(\sim 0.57$ for all samples except for LV $2.5 \%$ where SPAN was a bit higher (0.745)), and indeed, under optical microscopy, it was visible that the particles were not exactly the same in size.

Table 1.

Sphericity factor and average diameter of the alginate particles

\begin{tabular}{lcc}
\hline Sample & SF & Surface mean diameter $(\boldsymbol{\mu m})$ \\
\hline LV1\% & 0.038 & 368.5 \\
LV1.5\% & 0.027 & 429.3 \\
LV2.5\% & 0.016 & 754.8 \\
MV1\% & 0.026 & 588.9 \\
MV1.5\% & 0.024 & 672.1 \\
\hline
\end{tabular}



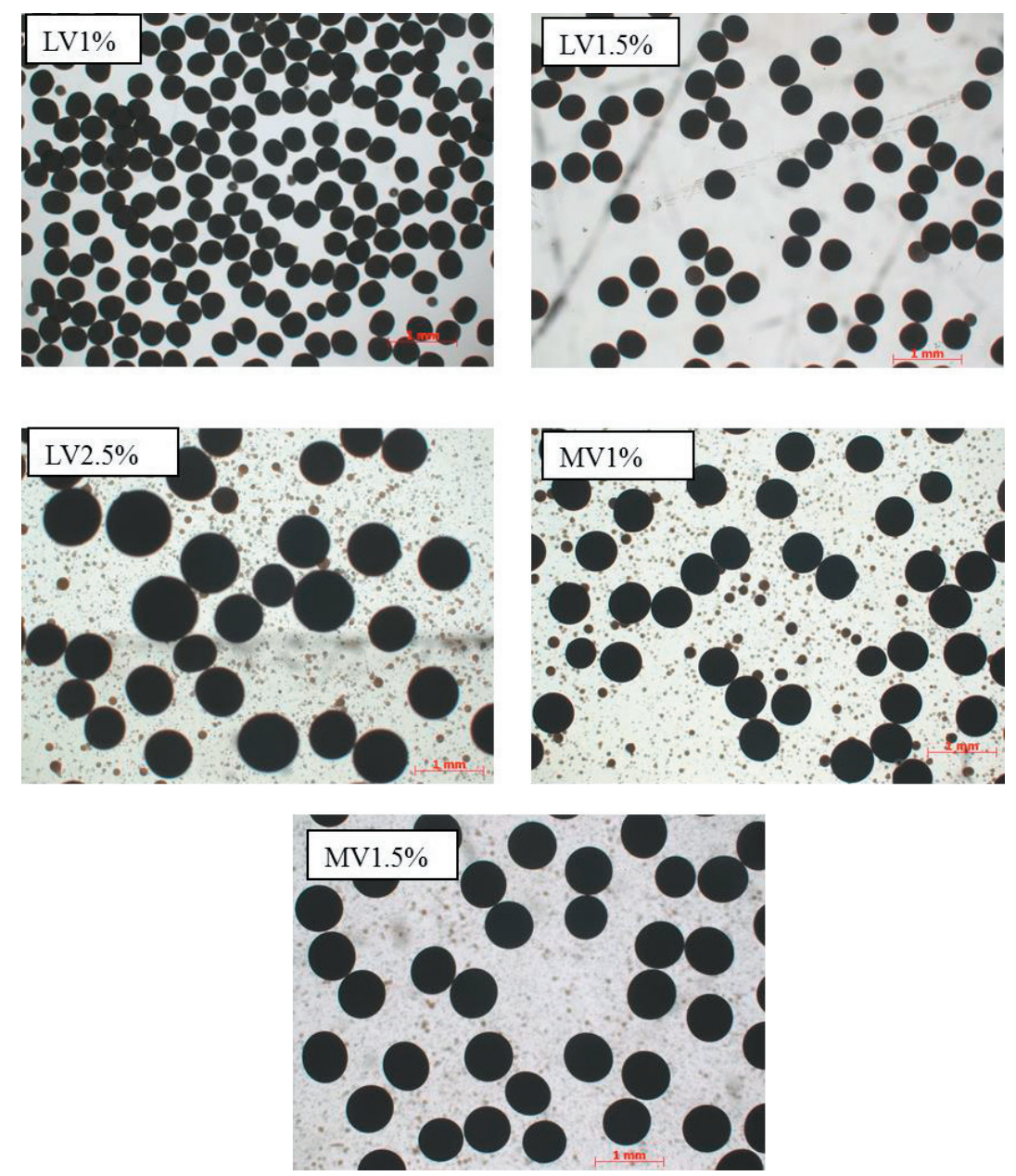

Figure 1. Optical microscopy of the alginate particles containing liposomes with encapsulated resveratrol

\section{Release studies}

The release of active compound (resveratrol) was monitored during 6 hours using Franz diffusion cell. Resveratrol concentration in samples was determined by spectrophotometry at $306 \mathrm{~nm}$. The results are presented in Figure 3 and they confirm the extended release of resveratrol from all formulations. The release profiles of resveratrol were compared for all liposomescontaining particles. Particles obtained using more concentrated alginate solution exhibited slower release of encapsulated active compound, which is in accordance with the previous studies (Dini et al., 2001; Dini et al., 2003). Thus, the slowest release of resveratrol was detected in the case of LV $2.5 \%$. For the sake of comparison, less than $40 \%$ of the originally entrapped resveratrol was released from LV $2.5 \%$ after approximately 330 minutes; while for the same time LV $1 \%$ release more than $60 \%$ of the initial resveratrol content. Apparently, higher alginate content provides thicker, i.e. less porous polymer network, so higher resistance to mass transfer. Our results are in agreement with literature data showing that the increase in particles porosity leads to poorer control of active compound release (Klose et al., 2006).

Moreover, even after 6 hours, none of the hydrogel particles released the total amount of resveratrol, probably due to interactions between alginate and resveratrol. Namely, the interactions between these two compounds occur via carboxylic and hydroxyl groups as revealed elsewhere (Cho et al., 2014; Istenič et al., 2015, Balanč et al., 2016). Furthermore, looking at the Figure 3 , it seems that the impact of alginate type (LV versus MV) on release properties was more obvious for the lower concentration (1\% versus $1.5 \%$ ). 


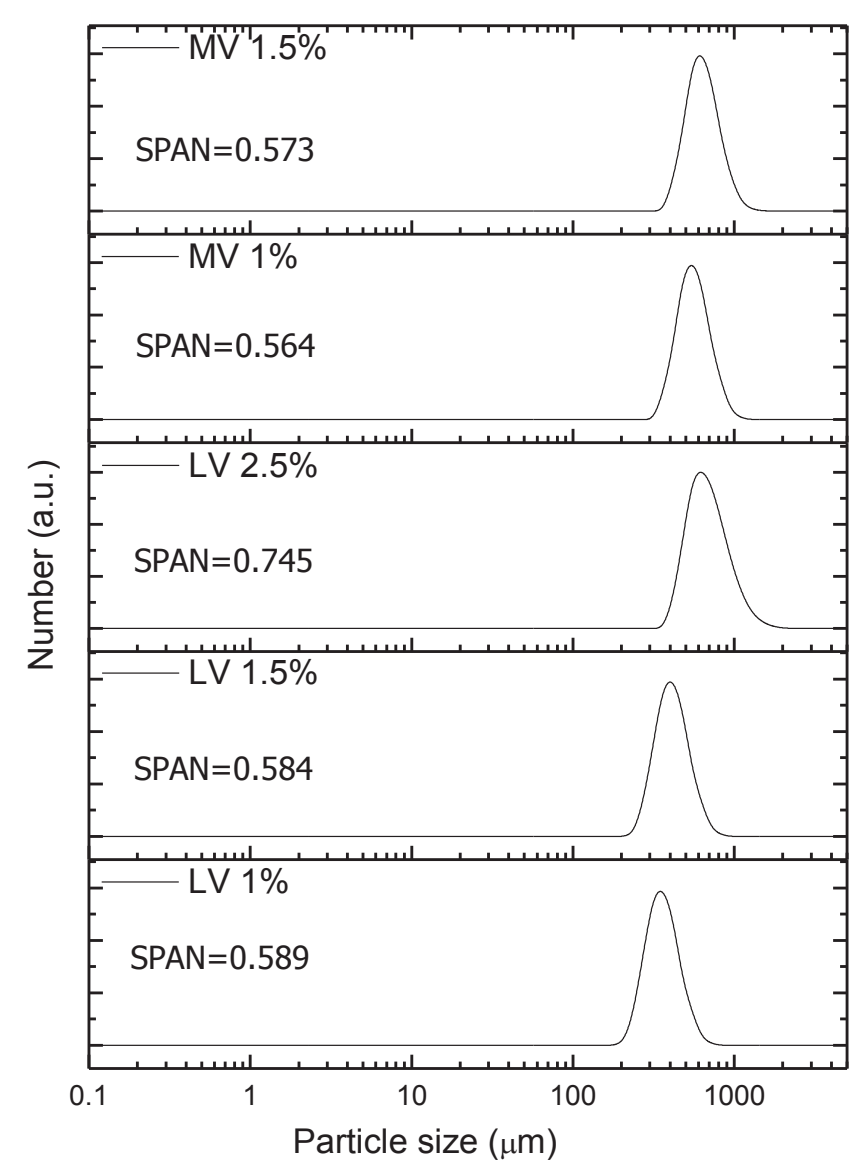

Figure 2. Size distribution of alginate particles containing liposomes with encapsulated resveratrol

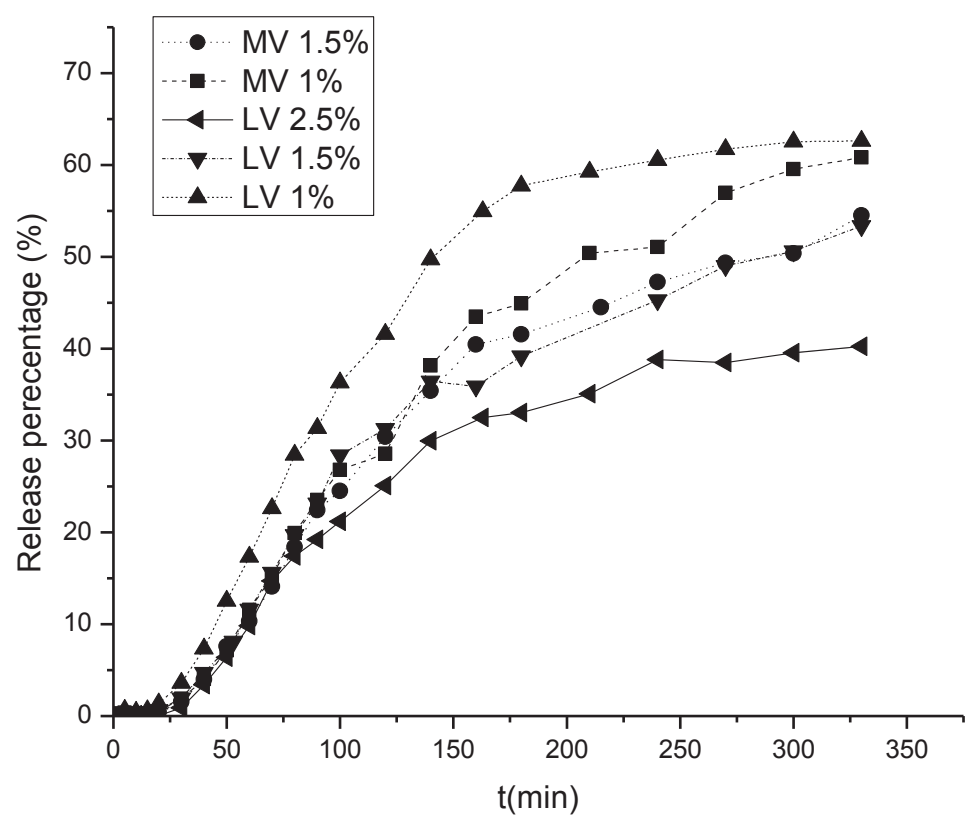

Figure 3. Release profiles of resveratrol from alginate particles containing liposomes 


\section{CONCLUSION}

Liposomes containing resveratrol were effectively encapsulated in alginate particles using electrostatic extrusion technique. The particles were spherical in shape and their size varied from 360 to 754 $\mu \mathrm{m}$ depending on polymer molecular weight and concentration in the starting solution. Polymer concentration also correlated with release time of resveratrol from the particles where the highest content of alginate induced the slowest release of resveratrol, probably due to the lower particle porosity. All samples had narrow distribution which was confirmed by SPAN values. Accordingly, complex systems such as liposomes containing resveratrol encapsulated in hydrogel particles can be easily prepared by the electrostatic extrusion using low and medium viscosity sodium-alginate up to $2.5 \%$ $(w / w)$. These results provide useful information and the basis for further application of these complex systems in the industry of functional food products.

\section{ACKNOWLEDGMENTS}

This work was supported by the Ministry of Education, Science and Technological Development, Republic of Serbia (Project No. III46010 "Novel encapsulation and enzyme technologies for a design of new biocatalysts and biologically active compounds aiming at enhancement of food quality, safety and competitiveness").

\section{REFERENCES}

1. Balanč, B., Trifković, K., Đorđević, V., Marković, S., Pjanović, R., Nedović, V., Bugarski, B. (2016). Novel resveratrol delivery systems based on alginate-sucrose and alginate-chitosan microbeads containing liposomes. Food Hydrocolloids, 61, 832-842.

2. Belščak-Cvitanović, A., Stojanović, R., Manojlović, V., Komes, D., Juranović Cindrić, I., Nedović, V, Bugarski, B. (2011). Encapsulation of polyphenolic antioxidants from medicinal plant extracts in alginate-chitosan system enhanced with ascorbic acid by electrostatic extrusion. Food Research International, 44 (4), 10941101.

3. Bugarski, B., Li, Q., Goosen, M.F.A., Poncelet, D., Neufeld, J.R., Vunjak, G. (1994). Electrostatic droplet generation: Mechanism of po- lymer droplet formation. AIChE Journal, 40 (6), 1026-1031.

4. Bugarski, B., Obradovic, B., Nedovic, V. Poncelet, D. (2004). Immobilization of cells and enzymes using electrostatic droplet generator. In Focus on biotechnology, vol 8a: Fundamentals of cell immobilisation biotechnology. Eds. V. Nedovic, R.G. Willaert, Kluwer Academic Publishers, Dordrecht, pp. 277-294.

5. Chan, E.S., Lim, T.K., Voo, W.P, Pogaku, R, Ti Tey, B., Zhang, Z. (2011). Effect of formulation of alginate beads on their mechanical behavior and stiffness. Particuology, 9 (3), 228-234.

6. Chan, E.S., Wong, S.L., Lee, P.P., Lee, J.S., Ti, T.B., Zhang, Z., Poncelet, D., Ravindra, P., Phan, S.H., Yim, Z.H. (2011). Effects of starch filler on the physical properties of lyophilized calcium-alginate beads and the viability of encapsulated cells. Carbohydrate Polymers, 83 (1), 225-232.

7. Cho, A.R., Chun, Y.G., Kim, B.K., Park, D.J. (2014). Preparation of alginate-CaCl2 microspheres as resveratrol carriers. Journal of Material Science, 49 (13), 4612-4619.

8. Dini, E., Alexandridou, S., Kiparissides, C. (2001). Synthesis and characterization of crosslinked microparticles for drug delivery. Chimia, 55 (3), 239-241.

9. Dini, E., Alexandridou, S., Kiparissides, C. (2003). Synthesis and characterization of cross-linked chitosan microspheres for drug delivery applications. Journal of Microencapsulation, 20 (3), 375-385.

10. Đorđević, V., Balanč, B., Belščak-Cvitanović, A., Lević, S., Trifković, K., Kalušević, A., Kostić, I., Komes, D., Bugarski, B., Nedović, V. (2015). Trends in encapsulation technologies for delivery of food bioactive compounds. Food Engineering Review, 7 (4), 452-490.

11. Isailović, B., Kostić, I., Zvonar, A., Đorđević, V., Gašperlin, M., Nedović, V., Bugarski, B. (2013). Resveratrol-loaded liposomes produced by different techniques. Innovative Food Science and Emerging Technology, 19, 181-189.

12. Istenič, K., Balanč, B.D., Djordjević, V.B., Bele, M., Nedović, V.A., Bugarski, B.M., Poklar Ulrih, N. (2015). Encapsulation of resveratrol into Caalginate submicron particles. Journal of Food Engineering, 167 B, 196-203.

13. Klimundova, J., Satinsky, D., Sklenarova, H., Solich, P. (2006). Automation of simultaneous release tests of two substances by sequential injection chromatography coupled with Franz cell. Talanta, 69 (3), 730-735.

14. Klose, D., Siepmann, F., Elkharraz, K., Krenzlin, S., Siepmann, J. (2006). How porosity and size affect the drug release mechanisms from PLGA-based microparticles. International Journal of Pharmaceutics, 314 (2), 198-206.

15. Kostić, I., Isailović, B., Đordević, V., Lević, S., Nedović, V., Bugarski, B. (2012). Electrostatic extrusion as a dispersion technique for encapsulation of cells and bioactive compounds. Chemical Industry, 66 (4), 503-515.

16. Lim, K.G., Gray, A.I., Anthony, N.G., Mackay, S.P., Pyne, S., Pine, N.J. (2014). Resveratrol 
and its oligomers: modulation of sphingolipid metabolism and signaling in disease. Archives of Toxicology, 88 (12), 2213-2232.

17. Lopez-Nicolas, M., Nunez-Delicado, E., PerezLopez, J. (2006). Determination of stoichiometric coefficients and apparent formation constants for cyclodextrin complexes of trans-resveratrol using reversed-phase liquid chromatography. Journal of Chromatography A, 1135 (2), 158-165.

18. Neves, A.R., Martins, S., Segundo, M.A., Reis, S. (2016). Nanoscale delivery of resveratrol towards enhancement of supplements and nutraceuticals. Nutrients, 8 (132).

doi:10.3390/nu8030131.

19. Pineiro, Z., Palma, M., \& Barroso, C.J. (2006). Determination of trans-resveratrol in grapes by pressurised liquid extraction and fast highperformance liquid chromatography. Journal of Chromatography A, 1110 (1-2), 61-65.

20. Prüsse, U., Bilancetti, L., Bucko, M., Bugarski, B., Bukowski, J., Gemeiner, P., Lewinska, D., Manojlović, V., Massart, B., Nastruzzi, C., Ne- dović, V., Poncelet, D., Siebenhaar, S., Tobler, L., Tosi, A., Vikartovska, A., Vorlop, K-D. (2008). Comparison of different technologies for the production of alginate microspheres. Chemical Papers, 62 (4), 364-374.

21. Stojanović, R, Belščak-Cvitanović, A, Manojlović, V., Komes, D., Nedović, V., Bugarski, B. (2012). Encapsulation of thyme (Thymus serpyllum L.) aqueous extract in calcium alginate beads. Journal of the Science of Food and Agriculture, 92 (3), 685-696.

22. Stojanović, S., Sprinz, H., Berde, O. (2001). Efficiency and mechanism of the antioxidant action of trans-resveratrol and its analogues in the radical liposome oxidation. Archives of Biochemistry and Biophysics, 391 (1), 79-89.

23. Trifković, K., Milašinović, N., Djordjević, V., Kalagasidis Krušić, M., Knežević-Jugović, Z., Nedović, V., Bugarski, B. (2014). Chitosan microbeads as carriers for encapsulation of thyme (Thymus serpyllum L.) polyphenols. Carbohydrate Polymers, 111, 901-907.

\title{
ИНКАПСУЛАЦИЈА РЕСВЕРАТРОЛА У СФЕРИЧНЕ ЧЕСТИЦЕ НА БАЗИ ХИДРОГЕЛОВА ДОЗВОЉЕНИХ ЗА УПОТРЕБУ У ХРАНИ
}

\author{
Бојана Д. Баланч ${ }^{1}$, Ката Т. Трифковић ${ }^{1}$, Верица Б. Ђорђевић ${ }^{1}$, Радослава Н. Правиловић ${ }^{1}$, \\ Смиља Б. Марковић ${ }^{2}$, Виктор А. Недовић ${ }^{3}$, Бранко М. Бугарски ${ }^{1}$ \\ ${ }^{1}$ Универзитет у Београду, Технолошко-металуршки фракултет, Катедра за хемијско инжењерство
${ }^{2}$ Институт техничких наука САНУ \\ ${ }^{3}$ Универзитет у Београду, Пољопривредни фракултет, Институт за прехрамбену технологију и \\ биохемију
}

Сажетак: Овај рад даје податке о припреми и карактеризацији честица које садрже липозоме са инкапсулираном активном компонентом ресвератролом. Компоненте које улазе у састав ових честица одабране су тако да могу једноставно да се примене у прехрамбеној индустрији. Приказан је утицај различитих концентрација почетних раствора полимера чија употреба је дозвољена у храни, а самим тим и њихове вискозности на величину формираних честица, њихов облик и расподелу величина, али и на отпуштање ресвератрола из ових сложених система. Пречник честица био је између 360 и $754 \mu \mathrm{m}$, док је уска расподела величина детектована у свим узорцима. Отпуштање ресвератрола праћено је у Францовој дифузионој ћелији где су резултати указали на продужено ослобађање ресвератрола у свим узорцима. Ипак, узорак који је имао највећи удео полимера у почетном раствору $(2,5 \% \mathrm{w} / \mathrm{w})$ најспорије је отпуштао активну компоненту. Ови резултати дају корисне податке о комплексним системима где је активна компонента инкапсулирана у липозоме даље обложена полимером чиме доприносе потенцијалној апликацији ових и сличних система у прехрамбене производе.

Кључне речи: ресвератрол, алгинат, отпуштање, сферичност, честице

Received: 3 April 2017

Accepted: 26 May 2017 